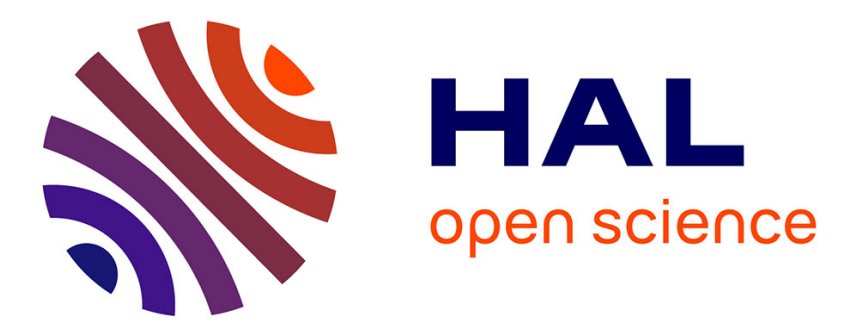

\title{
Efficient biofuel production from traditional maize under low input
}

Clara Serrano, Esperanza Monedero, Henar Portero, Elena Jiménez, Bernardo Ordás

\section{- To cite this version:}

Clara Serrano, Esperanza Monedero, Henar Portero, Elena Jiménez, Bernardo Ordás. Efficient biofuel production from traditional maize under low input. Agronomy for Sustainable Development, 2014, 34 (3), pp.561-567. 10.1007/s13593-013-0174-5 . hal-01234797

\section{HAL Id: hal-01234797 https://hal.science/hal-01234797}

Submitted on 27 Nov 2015

HAL is a multi-disciplinary open access archive for the deposit and dissemination of scientific research documents, whether they are published or not. The documents may come from teaching and research institutions in France or abroad, or from public or private research centers.
L'archive ouverte pluridisciplinaire HAL, est destinée au dépôt et à la diffusion de documents scientifiques de niveau recherche, publiés ou non, émanant des établissements d'enseignement et de recherche français ou étrangers, des laboratoires publics ou privés. 


\title{
Efficient biofuel production from traditional maize under low input
}

\author{
Clara Serrano • Esperanza Monedero • Henar Portero • \\ Elena Jiménez • Bernardo Ordás
}

Accepted: 22 July 2013 / Published online: 14 August 2013

(C) INRA and Springer-Verlag France 2013

\begin{abstract}
Traditional crop varieties are adapted to low inputs of fertilizers, pesticides, and water. In addition, biofuel from local vegetal biomass stimulates the economy in depressed rural areas. Biofuels also contribute to the reduction of greenhouse gas emissions. Here, we tested the suitability of traditional maize varieties as solid biofuel. We cultivated traditional maize varieties without pesticides and irrigation. Four varieties were cropped in two locations, with two fertilization levels, and harvested at three different dates. For each trait, we measured the heating value, the ash content, and the elemental composition. Results show that plants harvested at physiological maturity, 150 days after sowing, have about $10 \%$ more biomass and $20-30 \%$ less ash, $\mathrm{N}, \mathrm{K}$, and $\mathrm{Cl}$ than plants harvested 115 days after sowing. Moreover, reducing standard $\mathrm{N}$ input by $40 \%$ did not reduce the biomass yield. Calculations show that traditional maize varieties can produce an energy of $15-23 \cdot 10^{4} \mathrm{MJ} / \mathrm{ha}$. These findings demonstrate that traditional maize cultivation can be optimized to increase the efficiency of biomass production and to reduce the environmental impact.
\end{abstract}

Keywords Maize $\cdot$ Biomass $\cdot$ Yield $\cdot$ Heating value $\cdot$ Ash $\cdot$ Chlorine

\footnotetext{
C. Serrano $(\triangle) \cdot$ E. Monedero $\cdot H$. Portero

Instituto de Investigación en Energías Renovables, Universidad de Castilla-La Mancha, Calle Investigación s/n, Albacete 02006, Spain e-mail: clara.serrano@aol.com

E. Jiménez

Cespa S.A., Av. Catedral 6-8, $1^{a}$ planta, 08002 Barcelona, Spain

B. Ordás

Misión Biológica de Galicia, CSIC, Apartado 28, 36080 Pontevedra, Spain
}

\section{Introduction}

Traditional or local varieties of conventional crops are usually adapted to cultivation under low inputs (fertilizers, pesticides, and water) and perform relatively well under those conditions. Thus, traditional varieties have potential for sustainable agriculture aimed to meet current and future societal needs for food and fiber, for ecosystem services, and for healthy lives by maximizing net benefit to society when all costs and benefits of the practices are considered (Tilman et al. 2002). There is a growing social demand for this type of agriculture that, on the other hand, is mandatory in areas with specific regulations on promoting nature conservation and protecting biodiversity. In the case of maize, the seed of local varieties can be saved, leaving a part of the harvested seed for planting the next generation. This reduces the seed cost which, otherwise, has increased dramatically in recent years for commercial maize hybrids (Carena 2005) and makes the local varieties more appealing to organic or low-input farmers (Kutka and Smith 2007).

Biomass is a renewable energy source that contributes to mitigation of climate change, since the carbon emitted during combustion is balanced by the carbon fixed by photosynthesis. However, the overall balance of greenhouse gas emissions $\left(\mathrm{CO}_{2}, \mathrm{~N}_{2} \mathrm{O}, \mathrm{CH}_{4}\right)$ is not necessarily neutral because of emissions during the crop growth, field management, feedstock processing, and transport. For example, fertilizer application rates are directly linked to $\mathrm{N}_{2} \mathrm{O}$ emissions from soil and other greenhouse gas emissions coming from the fertilizer production and distribution (Don et al. 2011). Nitrogen in the fertilizer is also a potential source of groundwater pollution and eutrophication of rivers (Tilman et al. 2002; Ladha et al. 2005) which, in turn, have been associated to important health problems, for example, digestive cancer (Ebenstein 2010). The energetic use of crops, in addition to the environmental advantage, could also have social benefits, stimulating the establishment of new jobs in rural areas that are suffering a decline in population. 
With a $\mathrm{C}_{4}$ photosynthetic system, maize adapts to different environments and efficiently yields large amounts of grain and stover, with production rates comparable to those of dedicated energy crops such as Miscanthus or switchgrass (Reijnders 2010). Besides, as a traditional crop, it does not require high establishment costs, investment in new machinery, or experience needed for some new dedicated energy crops (Don et al. 2011). Thus, maize is considered a competitive crop for biogas production through anaerobic digestion in Central Europe (Amon et al. 2007; Schittenhelm 2008). Moreover, different thermal processes can be applied for electricity generation using maize. Searcy and Flynn (2010) found that, at present power and oil prices, direct combustion has lower social cost per unit of avoided greenhouse gas emissions than gasification in a combined cycle power plant.

In many areas, only one kind of feedstock, due to its limited availability, may not be sufficient to feed a biomass facility of optimum size. In such areas, Sultana and Kumar (2011) propose the combination of agricultural and woody feedstock as an economically attractive option for bioenergy production, although this requires a process that would be able to exploit both types of biomass (Fig. 1).

Knowledge of the thermochemical properties of biomass is important in order to assess the efficiency of the process and its environmental impact. For example, the nitrogen, chlorine, and sulfur contents of the fuel can affect the $\mathrm{NO}_{x}$, dioxins, furans, and $\mathrm{SO}_{x}$ emissions to the atmosphere. Moreover, the chlorine and sulfur contents are important with regard to corrosion problems in the heat exchanger of the combustion plant (Obernberger et al. 2006). Although some studies present the thermochemical properties of maize (Xiong et al. 2010; Wang et al. 2011), research on the effect that agronomic factors have on the heating value and other thermochemical properties of biomass is rare (Tao et al. 2012).

The objective of this research is to study the effect of harvesting date, fertilization level, and crop variety on agronomic

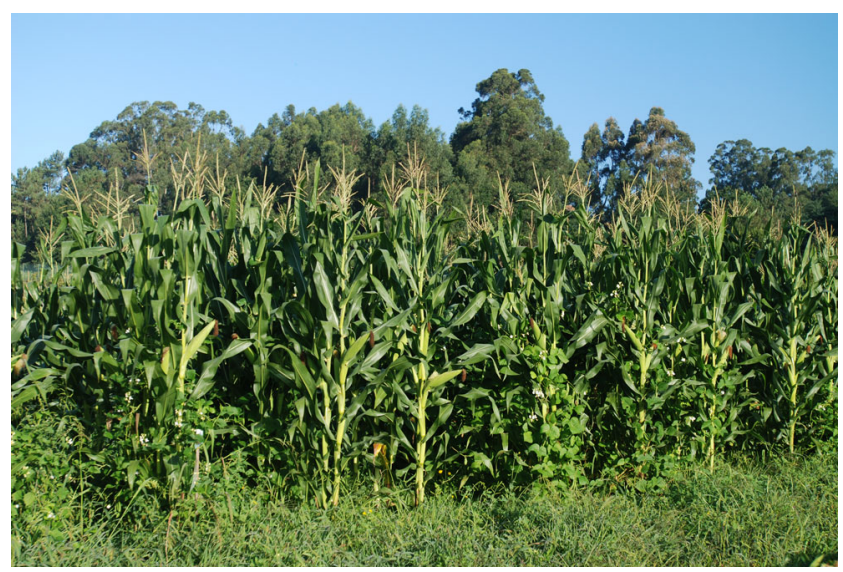

Fig. 1 In this work, traditional maize varieties without neither pesticides nor irrigation are evaluated with the aim of assessing their suitability as solid biofuel and thermochemical properties of maize biomass in order to optimize the sustainable production of heat and power based on combustion of traditional maize varieties cultivated under low-input conditions.

\section{Materials and methods}

\subsection{Experimental design}

The experimental design was a split-split plot design arranged as randomized complete blocks with three replicates. The main plot, subplot, and sub-subplots were fertilization, variety, and harvesting date, respectively.

From a preliminary evaluation of 15 local varieties (unpublished data), four open pollinated maize varieties adapted to temperate areas were selected for showing the highest biomass yield within their maturity cycle: BSL(S)C6 and Minnesota 13 (from northern USA) and Posada de Llanera and Lazcano (from northern Spain). Minnesota 13, Lazcano, Posada de Llanera, and BSL(S)C6 are early, earlymidseason, late-midseason, and late maturation varieties, respectively.

Two fertilization levels were used: the standard level in the area following the recommendations of Instituto Ourensán de Desenvolvemento Económico (INORDE), the Agricultural Extension Service of the Province Council (N, $258 \mathrm{~kg} / \mathrm{ha}$; $\mathrm{P}, 65.5 \mathrm{~kg} / \mathrm{ha} ; \mathrm{K}, 125 \mathrm{~kg} / \mathrm{ha}$; Ca, $21.4 \mathrm{~kg} / \mathrm{ha} ; \mathrm{Mg}, 8.4 \mathrm{~kg} / \mathrm{ha}$ ), and a reduced level (N, $157.5 \mathrm{~kg} / \mathrm{ha} ; \mathrm{P}, 39.3 \mathrm{~kg} / \mathrm{ha} ; \mathrm{K}, 75 \mathrm{~kg} /$ ha; $\mathrm{Ca}, 13.4 \mathrm{~kg} / \mathrm{ha} ; \mathrm{Mg}, 5.3 \mathrm{~kg} / \mathrm{ha}$ ). The plants were sown on May 22, 2011. Plants were sampled at three harvesting dates: at grain physiological maturity (150 days after sowing), 1 month before (115 days after sowing), and 1 month later (180 days after sowing).

Sowing was made manually to obtain a density of 80,000 plants/ha and the agronomic handling was done by INORDE following the local practices, without neither pesticides nor irrigation. At each sub-subplot, 100 plants were distributed in four rows. The 50 plants located in the two central rows were sampled for evaluation of dry matter yield. From those, seven to ten plants were randomly chosen and chopped for thermochemical analysis.

The experiment was repeated at two different locations: Baltar ( $41^{\circ} 56^{\prime} \mathrm{N}, 7^{\circ} 43^{\prime} \mathrm{W}$; $807 \mathrm{~m}$ above sea level) and Xinzo de Limia $\left(42^{\circ} 3^{\prime} \mathrm{N}, 7^{\circ} 43^{\prime} \mathrm{W}, 615 \mathrm{~m}\right.$ above sea level). Soil analyses were carried out before planting in both locations. The concentration of elements in Xinzo de Limia was as follows: N, $0.30 \%$; P, 22 ppm; K, 124 ppm; Ca, 312 ppm; and Mg, $84 \mathrm{ppm}$. The concentration of elements in Baltar was N, $0.25 \%$; P, 18 ppm; K, 116 ppm; Ca, 302 ppm; and Mg, 72 ppm.

Nitrogen mineralization capacity was determined by aerobic incubation during 6 weeks in one field in the area (González-Prieto et al. 1996), resulting a net immobilization 
of $2.02 \%$ of the organic nitrogen (Gonzalez-Prieto, personal communication). The climate can be considered of transition from Atlantic to Mediterranean in both locations. Due to its higher altitude, Baltar has higher precipitation and lower temperature than Xinzo de Limia (Fig. 2). Both are situated in an economically depressed rural area of Central Galicia (Spain), where agriculture is being abandoned and population is decreasing. Xinzo de Limia is located within A Limia, a Special Protection Area of Natura 2000 network, where farmers are required to replace some of their current crops with other crops with less need of pesticides to be grown.

\subsection{Determination of thermochemical properties of biomass}

One hundred and forty-four samples, corresponding to the combination of four varieties, three harvesting dates, two fertilization levels, and three replications within location and two locations, were analyzed in the laboratory. For those samples, the net heating value (NHV), the ash, carbon, hydrogen, nitrogen, sulfur, chlorine, and potassium contents were measured. In addition, in 36 of the samples, the calcium and silicon content were measured. All the analyses were repeated three times and were performed according to the European Committee for Standardization (CEN). Prior to its characterization, each sample was grounded to pass a $0.25-\mathrm{mm}$ screen by means of a cutting mill Retsch SM100 (CEN 2011d). The

\section{Precipitation (mm)}

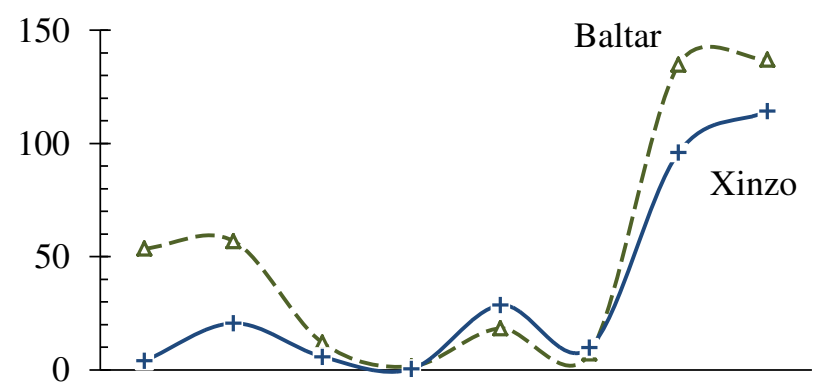

Temperature $\left({ }^{\circ} \mathrm{C}\right)$

(b)

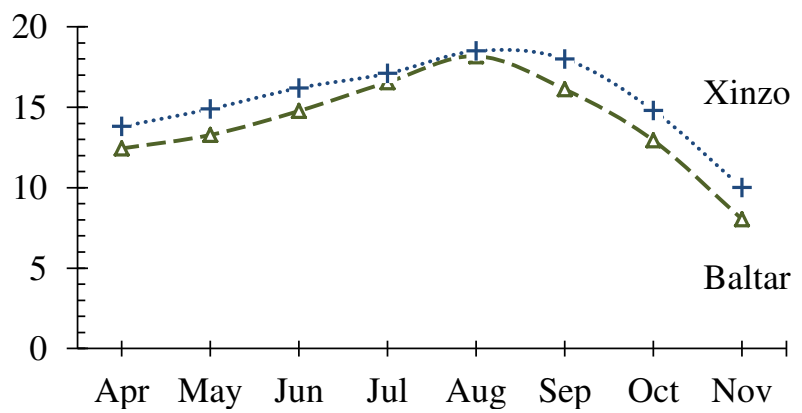

Fig. 2 Average monthly temperature and precipitation during the crop season in the two locations where the experiments were carried out net heating value was calculated from the gross heating value (measured in a compensated jacket calorimeter 6100 PARR) (CEN 2009b) and from the C, H, N, S, and $\mathrm{Cl}$ contents, measured by means of a LECO TruSpec CHNS analyzer and an ionic chromatograph analyzer (CEN 2011b, c). The ash content was analyzed in a furnace according to CEN (2009a), while the potassium, calcium, and silicon contents of the biomass were obtained by means of inductively coupled plasma atomic emission spectroscopy, after the acid digestion of the sample (CEN 2011a).

\subsection{Statistical analysis}

To analyze the effect of different factors on biomass productivity and thermochemical properties, an analysis of variance was performed with the PROC MIXED of SAS v9.2 (Cary, NC). This procedure was also used to estimate the means and their standard errors.

\section{Results and discussion}

\subsection{Moisture content and biomass yield}

Regarding yield, the residual variance of the experiment performed in Baltar was significantly higher $(F=3.6$, $P=0.0003$ ) than the residual variance of the experiment conducted in Xinzo de Limia. Therefore, the analysis of variance was carried out separately for the two experiments (data not shown). The harvesting date had a significant effect on the moisture content $(P<0.0001)$ and yield $(P<0.05)$ in both locations. Variety had a significant effect on the moisture content $(P<0.03)$ but not on yield, while the fertilization level did not influence any of these two agronomic traits. Most of the interactions between main factors were not significant. The yield of dry biomass and its moisture content, averaged over the two levels of fertilization, are shown in Table 1.

The highest moisture content was found for the first sampling (115 days after sowing); in the second sampling (150 days after sowing), the moisture decreased; while in the third (180 days after sowing), no further drying was achieved. The minimum value of the moisture content varied between varieties from about 50 to $65 \%$. Biomass that is collected with greater water content is generally more expensive to harvest, store, and transport (Hoskinson et al. 2007). Fagernas et al. (2010) reviewed the most promising commercially available drying processes, concluding that the choice of the drying process should be made after careful consideration of operational and economic factors specific to the application. Our results show that an appropriate choice of varieties could be a way of reducing the biomass moisture by $10 \%$ in the harvest. According to Hoskinson et al. (2007), further reductions could be achieved if the stalk bottoms are not harvested. In addition, 
Table 1 Dry matter yield and moisture content for four traditional maize varieties grown at two locations and harvested at three different dates. Average values over two levels of fertilization are presented in the table

\begin{tabular}{|c|c|c|c|c|c|c|c|c|c|c|c|c|c|c|c|c|}
\hline \multirow[b]{3}{*}{ Harvest $^{\mathrm{a}}$} & \multicolumn{8}{|c|}{ Location: Baltar } & \multicolumn{8}{|c|}{ Location: Xinzo } \\
\hline & \multicolumn{4}{|c|}{ Yield (t/ha) } & \multicolumn{4}{|c|}{ Moisture (wt \%) } & \multicolumn{4}{|c|}{ Yield (t/ha) } & \multicolumn{4}{|c|}{ Moisture (wt\%) } \\
\hline & 115 & 150 & 180 & Average & 115 & 150 & 180 & Average & 115 & 150 & 180 & Average & 115 & 150 & 180 & Average \\
\hline BSL(S)C6 & 10.3 & 11.8 & 14.9 & 12.3 & 80 & 67 & 66 & 71.0 & 9.9 & 10.7 & 8.5 & 9.7 & 77 & 63 & 63 & 67.7 \\
\hline Posada & 14.0 & 17.4 & 15.2 & 15.5 & 77 & 61 & 62 & 66.7 & 8.2 & 8.3 & 7.1 & 7.9 & 75 & 62 & 65 & 67.3 \\
\hline Lazcano & 13.3 & 16.5 & 12.6 & 14.1 & 77 & 56 & 66 & 66.3 & 8.0 & 8.6 & 7.4 & 8.0 & 73 & 52 & 58 & 61.0 \\
\hline Minnesota & 11.9 & 12.3 & 10.7 & 11.6 & 75 & 53 & 59 & 62.3 & 8.5 & 9.4 & 7.2 & 8.4 & 71 & 51 & 53 & 58.3 \\
\hline Average & 12.4 & 14.5 & 13.4 & - & 77.3 & 59.3 & 63.3 & - & 8.7 & 9.3 & 7.6 & - & 74.0 & 57.0 & 59.8 & - \\
\hline Standard error & 1.36 & 1.36 & 1.36 & - & 2.3 & 2.3 & 2.3 & - & 1.0 & 1.0 & 1.0 & - & 1.7 & 1.7 & 1.7 & - \\
\hline
\end{tabular}

${ }^{\mathrm{a}}$ Days from sowing to harvest

the exclusion of stalk bottoms may lessen the amount of soil adhered to the lower stem, which may improve the crop quality. On the other hand, if the stalk bottoms are not harvested, the yield is reduced.

The maximum yield was achieved 150 days after sowing at both locations for all varieties, except for BSL(S)C6 cropped at Baltar (Table 1). This maximum corresponds, approximately, to the time of kernel physiological maturity for most of the varieties, and yield shows a decrease after that moment. Pordesimo et al. (2005) explain such decline for the break of leaf blades, tassels, tops of stalks, and husk leaves, which in turn is due to weathering (wind and rainfall). In Baltar, the maximum biomass yields can be considered relatively high (about $15-17 \mathrm{t} / \mathrm{ha}$ ) for traditional varieties that were not subjected to an intense selection program. All varieties showed lower biomass yields (about 8-11 t/ha) in Xinzo than in Baltar, probably due to a drought stress suffered in the former location.

We found that reducing by almost half the standard amount of fertilizer typically applied in the region did not affect the biomass yield. Lafitte and Edmeades (1994) also found cultivars of maize that do not respond to high levels of fertilization and perform relatively well under low fertilization levels (better than nitrogen responsive hybrids). Reducing the excess of nitrogen from agriculture would benefit water quality, decrease coastal eutrophication, improve air quality, and aid significantly in greenhouse gas mitigation (Houlton et al. 2013).

\subsection{Net heating value and ash content}

According to the analysis of variance, the harvesting date had a significant effect on all the biomass properties, except sulfur at Xinzo (data not shown). Variety had a significant effect on the net heating value and nitrogen and sulfur contents in Baltar, while fertilization had a $5 \%$ significant effect on nitrogen $(P=0.0495)$ and an effect significant at $10 \%$ of probability on chlorine $(P=0.0958)$ in Xinzo.
The net heating value ranged between 16 and $17 \mathrm{MJ} / \mathrm{kg}$, expressed on a dry basis, in our samples. The firstly harvested samples showed the highest energy content $(16.64 \mathrm{MJ} / \mathrm{kg}$ on average), while the secondly harvested ones showed the lowest energy content (16.17 MJ/kg on average) (Fig. 3a). The energy

\section{Energy output (MJ/kg)}

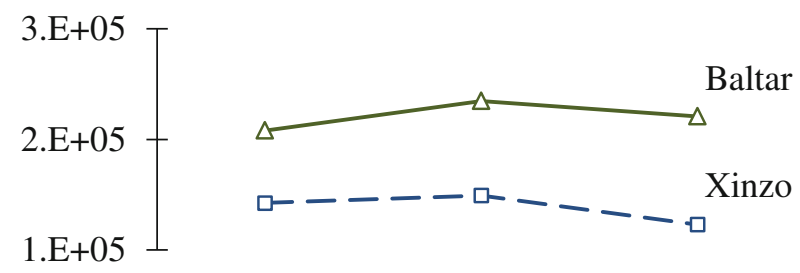

Net heating value $(\mathrm{MJ} / \mathrm{kg})$

(b)

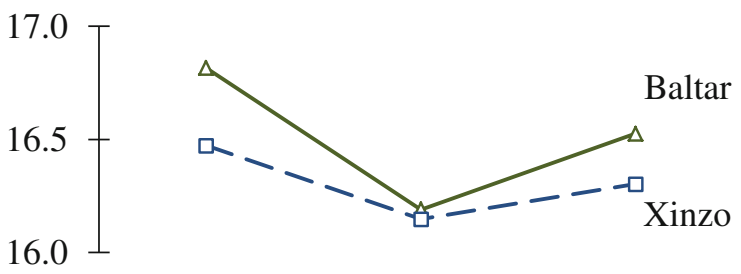

Ash content (wt\%, d.b.)

(c)

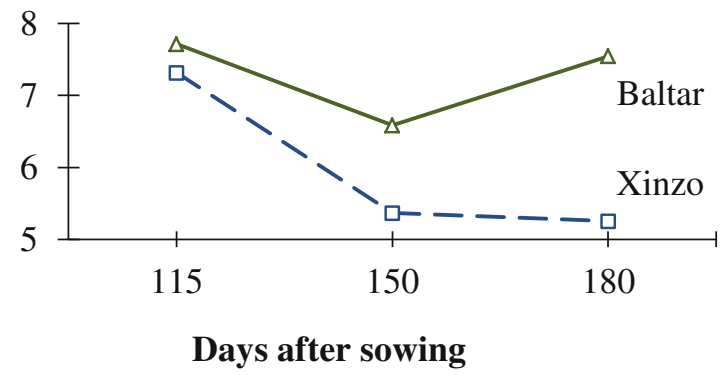

Fig. 3 Net heating value (energy per dry matter kilogram) and energy output (energy per hectare) for traditional maize varieties. Average values over two levels of fertilization, four varieties, and two locations are presented in the figure 
output (the total energy obtained per hectare) was higher by harvesting 150 days after sowing $(1.92 \mathrm{MJ} / \mathrm{ha})$ than 1 month before $(1.74 \mathrm{MJ} / \mathrm{ha}$ ) (Fig. 3b). This is because the samples harvested 150 days after sowing had higher biomass yield (11.9 t/ha vs $10.5 \mathrm{t} / \mathrm{ha}$ ), which compensates their lower NHV $(16.17 \mathrm{MJ} / \mathrm{kg}$ vs $16.64 \mathrm{MJ} / \mathrm{kg})$. This highlights the importance of jointly assessing agronomic and thermochemical properties to optimize the sustainable production of heat and power.

Instead of the NHV, results of the gross heating value are given in other works (Zhao et al. 2008; Xiong et al. 2010; Wang et al. 2011). In contrast with the gross value, the net value refers to combustion conditions such that all the water of the reaction products remains as water vapor (do not condensate). It is the net value that is used to evaluate the feedstock needed per kilowatt produced in a power plant. If the gross values found in references are converted into net values, results are similar to the results obtained in this work.

The ash content of our samples ranged from 4.7 to $8.4 \mathrm{wt} \%$, being close to the average value ( $6.6 \mathrm{wt} . \%)$ found by Tao et al. (2012), who review more than 30 studies on the ash content of maize stover. The ash content of a fuel is important for assessing the efficiency of the combustion process because high ash contents threat the plant operation through slagging and fouling problems. The highest ash content was usually found in the firstly harvested samples which had 1-2\% (absolute value) less ash than the secondly harvested samples (Fig. 3c). Therefore, a reduction in the ash content can be achieved without any cost by just selecting the harvesting moment.

\subsection{Elemental composition}

In contrast with the rest of the thermochemical properties, the carbon, hydrogen, and oxygen contents usually differ much less over different biomass varieties and assortments (Tao et al. 2012). In our samples, the carbon, oxygen, and hydrogen contents of maize were relatively stable over locations, varieties, and fertilization levels. Besides, the carbon, oxygen, and hydrogen contents $(45,40$, and $6 \%$, respectively) were similar to the values found for maize stover by other researchers (Hoskinson et al. 2007; Xiong et al. 2010; Wang et al. 2011).

The chlorine and potassium contents decreased along harvesting dates; however, the nitrogen content decreased in the second harvest, but increased in the third (Fig. 4). No clear tendency of the sulfur content with the harvesting date was observed. The nitrogen and chlorine contents increased with fertilization for all harvesting dates in Xinzo (Table 2). Therefore, a reduction in the emissions associated to chlorine and nitrogen could be achieved, according to our results, by harvesting once the grain has reached its physiological maturity and by decreasing the fertilization level that, on the other hand, does not seem to enhance the biomass yield.

\section{Concentration (wt\%, d.b.)}

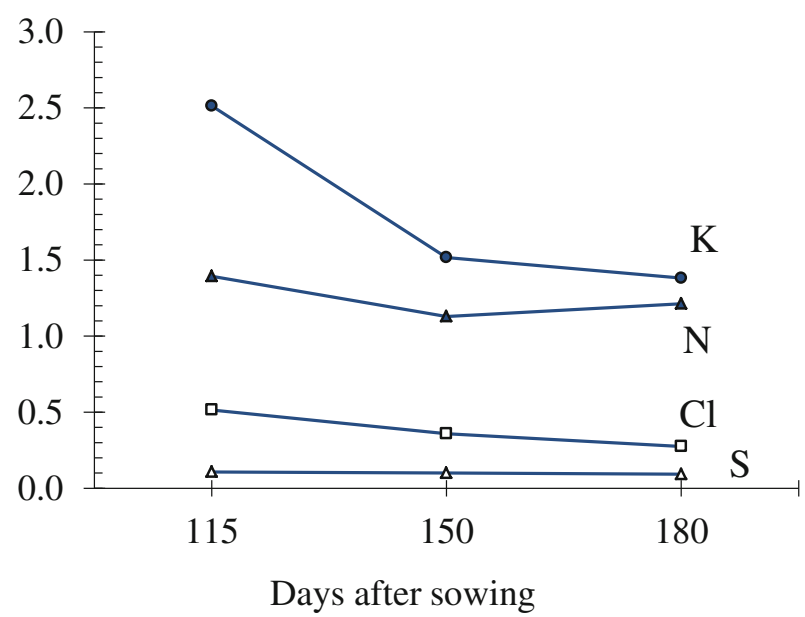

Fig. 4 Potassium, nitrogen, chlorine, and sulfur contents for traditional maize varieties. Average values over two levels of fertilization, four varieties, and two locations are presented in the figure

Nitrogen, chlorine, and sulfur in our samples are in the range of magnitude found by other authors in maize samples (Xiong et al. 2010; Avila-Segura et al. 2011). These elements lead to hazardous emissions to the atmosphere during combustion (dioxins, furans, $\mathrm{NO}_{x}$, and $\mathrm{SO}_{x}$ ). The chlorine, sulfur, and particularly the nitrogen content, even in the most appropriate harvesting date and fertilization level $(1.1,0.3$, and $0.1 \%$, respectively), were close to or above the limits given by Obernberger et al. (2006) for unproblematic combustion (pollutant emission and/or corrosion). According to these authors, low concentration of calcium and high concentration of silicon, as found in our samples ( 0.29 and 0.84 , respectively), decrease the temperature at which the ash starts melting. Technological countermeasures to control the emission and corrosion problems include selective catalytic reduction, air staging, automatic heat exchanger cleaning systems, coating of boiler tubes, etc. (Obernberger et al. 2006). In addition, $\mathrm{NO}_{x}$ emissions could be reduced by burning only the stover (Avila-Segura et al. 2011).

Table 2 Nitrogen and chlorine contents at two fertilization rates and at three harvested dates for traditional maize varieties grown at Xinzo. Average values over four varieties are presented in the table

\begin{tabular}{lllll}
\hline \multicolumn{5}{c}{ Fertilization rate } \\
\cline { 2 - 5 } Harvest $^{\mathrm{a}}$ & $\begin{array}{l}\text { Low } \\
\text { Nitrogen } \\
(\%)\end{array}$ & Medium & $\begin{array}{l}\text { Low } \\
\text { Chlorine } \\
(\%)\end{array}$ & Medium \\
\hline 115 & 1.25 & 1.70 & 0.46 & 0.80 \\
150 & 1.11 & 1.42 & 0.38 & 0.49 \\
180 & 1.18 & 1.50 & 0.21 & 0.35 \\
Standard error & 0.07 & 0.07 & 0.08 & 0.08 \\
\hline
\end{tabular}

${ }^{\mathrm{a}}$ Days from sowing to harvest 
The nitrogen and sulfur contents tended to be lower in the late maturing varieties (BSL(S)C6 and Posada de Llanera) than in the early maturing varieties (Lazcano and Minnesota 13) in Baltar. This is probably due to the short summer and relatively low temperatures, which provokes a slow maturation of the grain, the part of the plant that accumulates more nitrogen and sulfur (Avila-Segura et al. 2011). Some authors have proposed late maturing varieties of maize for bioenergy because they are able to capture a larger amount of radiation, a more favorable source-to-sink ratio, and higher reserve remobilization potential (Herrmann and Rath 2012).

\section{Conclusion}

We conclude that some agronomic practices can be optimized to increase the efficiency of the production of heat and power based on biomass combustion and to reduce the environmental impact. Our results show that harvesting maize at the physiological maturity of the grain has positive effects in most of the agronomic and thermochemical properties. In addition, an appropriate choice of variety can decrease the moisture content by $10 \%$, while the normal fertilization level can be reduced without lowering the biomass yield.

According to our data, the production of heat and power based on the combustion of traditional maize varieties cultivated under low-input conditions (no irrigation, no pesticides, and low fertilization) can be valuable for sustainable agriculture. This is so because the costs and environmental impacts are reduced while the biomass yield and the net heating value are relatively high. The main environmental constrain could be the $\mathrm{NO}_{x}$ emissions due to the high nitrogen content of the samples which could be reduced if only the stover is burned.

Acknowledgments This work was supported by Cespa S.A. (Spanish company working on waste management and biomass-to-energy conversion), the Castilla-La Mancha Government (project POII10-0128-1789), and the Xunta de Galicia (through the Parga Pondal program and project 09MRU033403PR). The authors also thank INORDE for its participation in the project. B. Ordas thanks Serafin Gonzalez-Prieto for his valuable help.

\section{References}

Amon T, Amon B, Kryvoruchko V, Zollitsch W, Mayer K, Gruber L (2007) Biogas production from maize and dairy cattle manure - influence of biomass composition on the methane yield. Agric Ecosyst Environ 118:173-182. doi:10.1016/j.agee.2006.05.007

Avila-Segura M, Barak P, Hedtcke JL, Posner JL (2011) Nutrient and alkalinity removal by corn grain, stover and cob harvest in upper Midwest USA. Biomass Bioenergy 35:1190-1195. doi:10.1016/j. biombioe.2010.12.010

Carena MJ (2005) Maize commercial hybrids compared to improved population hybrids for grain yield and agronomic performance. Euphytica 141:201-208. doi:10.1007/s10681-005-7072-0
CEN (2009a) Determination of ash content. EN 14775 Comité Européen de Normalisation, Brussels

CEN (2009b) Determination of calorific value. EN 14981 Comité Européen de Normalisation, Brussels

CEN (2011a) Determination of major elements Al, Ca, Fe, Mg, P, K, Si, $\mathrm{Na}$ and Ti. EN 15290 Comité Européen de Normalisation, Brussels

CEN (2011b) Determination of total content of carbon, hydrogen and nitrogen-instrumental methods. EN 15104 Comité Européen de Normalisation, Brussels

CEN (2011c) Determination of total content of sulfur and chlorine. EN 15289 Comité Européen de Normalisation, Brussels

CEN (2011d) Sample preparation. EN 14780 Comité Européen de Normalisation, Brussels

Don A, Osborne B, Hastings A, Skiba CMS, Drewer J, Flessa H, Freibauer A, Hyvonen N, Jones MB, Lanigan GJ, Mander U, Monti A, Djomo SN, Valentine J, Walter K, Zegada-Lizarazu W, Zenone $\mathrm{T}$ (2011) Land-use change to bioenergy production in Europe: implications for the greenhouse gas balance and soil carbon. GCB Bioenergy 4:372-391. doi:10.1111/j.1757-1707.2011.01116.x

Ebenstein A (2010) The consequences of industrialization: evidence from water pollution and digestive cancers in China. Rev Econ Stat 94:186-201. doi:10.1162/REST_a_00150

Fagernäs L, Brammer J, Wilén C, Lauer M, Verhoeff F (2010) Drying of biomass for second generation synfuel production. Biomass Bioenergy 34:1267-1277. doi:10.1016/j.biombioe.2010.04.005

González-Prieto SJ, Cabaneiro A, Villar MC, Carballas T, Carballas M (1996) Effect of soil characteristics on $\mathrm{N}$ mineralization capacity in 112 native and agricultural soils from the northwest of Spain. Biol Fertil Soils 22:252-260. doi:10.1007/BF00382521

Herrmann A, Rath J (2012) Biogas production from maize: current state, challenges and prospects. 1 . Methane yield potential. Bioenergy Res 5:1027-1042. doi:10.1007/s12155-012-9202-6

Hoskinson RL, Karlen DL, Birrell SJ, Radtke CW, Wilhelm WW (2007) Engineering, nutrient removal, and feedstock conversion evaluations of four corn stover harvest scenarios. Biomass Bioenergy 31:126-136. doi:10.1016/j.biombioe.2006.07.006

Houlton B, Boyer E, Finzi A, Galloway J, Leach A, Liptzin D, Melillo J, Rosenstock T, Sobota D, Townsend A (2013) Intentional versus unintentional nitrogen use in the United States: trends, efficiency and implications. Biogeochem 114:11-23. doi:10.1007/s10533012-9801-5

Kutka FJ, Smith ME (2007) How many parents give the highest yield in predicted synthetic and composite populations of maize? Crop Sci 47:1905-1913. doi:10.2135/cropsci2006.12.0802sc

Ladha JK, Pathak H, Krupnik T, Six J, van Kessel C (2005) In: Donald LS (ed) Efficiency of fertilizer nitrogen in cereal production: retrospects and prospects. Advances in agronomy, 1st edn. Elsevier, New York, pp 85-156

Lafitte HR, Edmeades GO (1994) Improvement for tolerance to low soil nitrogen in tropical maize I. Selection criteria. Field Crops Res 39:114. doi:10.1016/0378-4290(94)90066-3

Obernberger I, Brunner T, Bärnthaler G (2006) Chemical properties of solid biofuels - significance and impact. Biomass Bioenergy 30:973-982. doi:10.1016/j.biombioe.2006.06.011

Pordesimo LO, Hames BR, Sokhansanj S, Edens WC (2005) Variation in corn stover composition and energy content with crop maturity. Biomass Bioenergy 28:366-374. doi:10.1016/j.biombioe.2004.09.003

Reijnders L (2010) Transport biofuel yields from food and lignocellulosic C4 crops. Biomass Bioenergy 34:152-155. doi:10.1016/j.biombioe. 2009.10.004

Schittenhelm S (2008) Chemical composition and methane yield of maize hybrids with contrasting maturity. Eur J Agron 29:72-79. doi:10. 1016/j.eja.2008.04.001

Searcy E, Flynn PC (2010) A criterion for selecting renewable energy processes. Biomass Bioenergy 34:798-804. doi:10.1016/j.biombioe. 2010.01.023 
Sultana A, Kumar A (2011) Optimal configuration and combination of multiple lignocellulosic biomass feedstocks delivery to a biorefinery. Bioresour Technol 102:9947-9956. doi:10.1016/j. biortech.2011.07.119

Tao G, Geladi P, Lestander TA, Xiong S (2012) Biomass properties in association with plant species and assortments. II: A synthesis based on literature data for ash elements. Renew Sustain Energy Rev 16:3507-3522. doi:10.1016/j.rser.2012.01.023

Tilman D, Cassman KG, Matson PA, Naylor R, Polasky S (2002) Agricultural sustainability and intensive production practices. Nature 418:671-677. doi:10.1038/nature01014
Wang L, Shahbazi A, Hanna MA (2011) Characterization of corn stover, distiller grains and cattle manure for thermochemical conversion. Biomass Bioenergy 35:171-178. doi:10.1016/j.biombioe.2010.08.018

Xiong S, Zhang Y, Zhuo Y, Lestander TA, Geladi P (2010) Variations in fuel characteristics of corn (Zea mays) stovers: General spatial patterns and relationships to soil properties. Renew Energy 35:1185-1191. doi:10.1016/j.renene.2009.11.032

Zhao W, Li Z, Wang D, Zhu Q, Sun R, Meng B, Zhao G (2008) Combustion characteristics of different parts of corn straw and NO formation in a fixed bed. Bioresour Technol 99:2956-2963. doi:10. 1016/j.biortech.2007.06.030 